\title{
Epidemiological, Clinical and Psychometric Aspects of Autism Spectrum Disorder among Children in Zagazig University Hospital
}

\author{
Hanaa A. Nofal MD ${ }^{1}$, Amany M. AbdAllah MD ${ }^{2 *}$, Mona S. Hamed MD ${ }^{1}$ \\ ${ }^{1}$ Community Medicine Department, Faculty of Medicine, Zagazig University, Egypt \\ ${ }^{2}$ Family Medicine Department, Faculty of Medicine, Zagazig University, Egypt
}

\begin{abstract}
:
Background: Autism spectrum disorder (ASD) is a severe psychiatric disorder of childhood that entails severe difficulties in verbal, non verbal communication, language development, repetitive and limited patterns of behaviors, and obsessive resistance to small changes in familiar surrounding. Objectives: to assess the role of epidemiological, clinical and psychiatric determinants as risk factors of ASD. Methods: A case control study was conducted on 72 ASD children attending psychiatric outpatient clinic, and 72 healthy children. Their caregivers completed a questionnaire about risk factors for ASD. Then they underwent complete assessment of mental age using Stanford-Binet intelligence scale, childhood autism rating scale to outline severity of ASD in cases and exclude presence of autistic features in controls. Results: There is a statistically significant difference between both groups regarding parents' education, fathers' age at conception time, family history of psychiatric disorders, history of ovulation induction, hypertension during pregnancy, folic acid supplementation during $1^{\text {st }}$ trimester of pregnancy, use of anti $\mathrm{D}$, history of postnatal hypoxia, admission to NICU, and diet type. A significant difference between the two groups concerning reaction to others and delayed developmental milestones was found. About $63 \%$ and $58 \%$ had severe autism and mild to severe mental retardation respectivey. Paternal age, positive family history of psychiatric diseases, postnatal hypoxia significantly increased risk of ASD. Folic acid supplementation during $1^{\text {st }}$ trimester of pregnancy significantly decreased ASD risk. Conclusion: Family history of psychiatric disorders, advanced fathers' age at time of conception, and postnatal hypoxia were significant risk factors. Folic acid supplementation during the $1^{\text {st }}$ trimester is a significant protector.
\end{abstract}

Key words: Autism, Psychiatric, Supplementation

\section{Introduction:}

The ASD is one of several pervasive developmental disorders, and it encompasses a group of clinical syndromes that have two fundamental manifestations: developmental delays and developmental deviations ${ }^{(1)}$. Autism affects boys four to five times more than girls. The prevalence of autism was stated to be $2-5$ in 10,000 in 1990. ${ }^{(2)}$ CDC, however, declared that ASD affects around 52 millions worldwide in 2015. ${ }^{(3)}$ Unfortunately, in Egypt, there are no statistics accounting for the actual incidence and prevalence of ASD due to the substantial confusion between ASD and a several other different disabilities. ${ }^{(4)}$ In Arab counteries, the prevalence of ASD was 1.4 per 10,000 in Oman, 4.3 per 10,000 in Bahrain and 29 per 10,000 for PDD in UAE. ${ }^{(5-7)}$ The most obvious clinical presentation of autism tend to appear between 2 and 3 years of age. ${ }^{(8)}$ Autism has also a fundamental genetic component although the number of that genes may be involved remains unclear. ${ }^{(9)}$ The most commonly defined underpinning facctors are the structural and numerical abnormalities of sex chromosomes, namely

*Corresponding author: E-mail: dr.amanymohammed@ gmail.com 
anomalies of chromosome 15 and chromosome $17 \mathrm{q} 21 .^{(10)}$

Despite significant research on prenatal, perinatal, neonatal, and other risk factor in autism, the causal nature of these associations is still unclear due to several current methodological limitation of studies. So this study was carried out to assess the role of epidemiological, clinical and psychiatric determinants as risk factors of ASD.

\section{Methods:}

Study design and setting: A case-control study was conducted. Autistic children were recruited from psychiatric outpatient clinic in Zagazig University, from May to November (2019). Heathy control group was recruited from outpatient pediatric clinics of Zagazig University hospital.

Study sample and technique: Assuming that frequency of positive family history for psychiatric diseases among autistic patients was $18.3 \%$, and $2.8 \%$ among healthy control group ${ }^{(\mathbf{1 1})}$ with a ratio of exposed to non-exposed 1:1, the sample size was 61 per each group plus $20 \%$ to compensate for potential dropout so the total sample was 73 participants per group. Sample size was calculated using OpenEPI software with power of study $80 \%$ and Confidencr level of $95 \%$. The sample was collected using a systematic random technique, the attendance rate of autistic childern was 30 per month and 15 autistic childern were needed to be included each month, accordingly each second autistic child was selected until the desired sample was completed within 5 months. Subsequently, one matched healthy control for each child was added. Both autistic cases and controls were matched in terms of age and sex.

\section{Study tools:}

\section{An interviewing questionnaire was designed to collect:}

- Socio-demographic data including: For child: name, gender, age, and his/her mother: age, marital status, level of education, occupation. For Father: age, level of education, occupation, consanguinity, and income.

- Complete history tracking including:

- Antenatal history: age of mother during pregnancy of the child, history of ovulatoin induction, presence of complications (bleeding during pregnancy, rubella, diabetes mellitus, hypertension, preeclampsia, convulsions), using of drugs (e.g.: antiepileptic drugs, anti-thyroid drugs, anti-D injection), and exposure to radiation.

- Natal history: type of delivery, presentation, and place and time of birth.

- Postnatal history: Birth weight, resuscitation, jaundice, admission to 
neonatal ICU, and congenital anomalies.

- Developmental history; motor and mental including Age of recognizing mother, and father, sitting unassisted, walking unassisted, saying a word, saying a sentence, and admission to school.

- Vaccination history: BCG, oral polio, hepatitis B,DPT, MMR vaccines, gross and fine motor functions, and abnormal sleep patterns.

- Nutritional history: Breast feeding or artificial feeding, time of weaning and any feeding disorders.

- Past history including: major childhood illnesses, any previous therapies used to treat the child's condition.

- Family History including: Family history for any psychiatric diseases in the family.

\section{Psychiatric evaluation:}

This diagnosis was confirmed using DSMVcriteria of autism ${ }^{(8)}$ i.e. impairments of language, social skills, and restricted stereotyped interest or activity criteria of autism.

Assessment of mental age: Stanford-Binet intelligence scale $(1986)^{(12)}$ was used to calculate the intelligence quotient (IQ). This test was used to measure the child's cognitive abilities. It was suitable for children aging from 2 to 16 years, and it included two items, the verbal and the performance. The test item was chosen according to the child abilities. IQ was calculated by dividing the mental age by the chronological age multiplied by 100 . Subnormal intellectual function was diagnosed when IQ is below 70. Arabic version by Melika ${ }^{(13)}$ was used.

Assessment of severity of autistic symptoms: It is done by using childhood autism rating scale (CARS) where the child was rated on a scale from one to four in each of fifteen areas relating to people, emotional response, imitation, body use, object use, listening response, fear or nervousness, verbal communication, nonverbal communication, activity level, consistency of intellectual response, adaptation to change,visual response, taste, smell, touch response and general impression. ${ }^{(14)}$

The questionnaire was translated from English to Arabic by an expert translator, then back-translated by another expert translator, and finally, the original and translated versions were compared by another bilingual expert to ensure the questionnaire's validity. The reliability coefficient test (Cronbach's alpha) was $=$ 0.72 for all questions in CARS questionnaire.

\section{Operational design:}

Pilot study: A pilot study was conducted on $10 \%$ of the total studied autistic childern 
to evaluate the content and clarity of the tools, and to estimate the time needed for data collection. The necessary modifications were implemented, and the results of pilot study were not included in the study.

Field work: All mothers of the studied children were interviewed, and were asked to complete the study questionnaires. The ASD symptoms of studied patients were diagnosed using DSM-V criteria of autism. ${ }^{(8)}$

Both groups of children underwent assessment of mental age using StanfordBinet intelligence scale, $4^{\text {th }}$ edition ${ }^{(12)}$ to calculate the intelligence quotient (IQ). This test is used to measure the child's cognitive abilities. Additionally, all of them completed childhood autism rating scale to outline severity of ASD in cases, and to exclude the presence of autistic features in the control group.

Statistical analysis: Data analysis was performed using the software SPSS (Statistical Package for the Social Sciences) version 20. Categorical variables were described using their absolute frequencies and were compared using Chi square test and Fisher exact test when appropriate. Binary logistic regression was used to identify potential risk factors of ASD among the studied children. The level of statistical significance was set at $5 \%$
$(P<0.05)$. If $\mathrm{p} \leq 0.001$, the difference is deemed significant.

Ethical consideration: Administrative approval was obtained from Ethical comimittees in Faculty of Medicine, Zagzig Univeraity IRB\#5741 May 24, 2019 and the manager of Psychiatry department . Informed consents were obtained from guardians of all children after explanation the objectives, benefits, risks of the study. Confidentiality of the individual data was assured.

\section{Results:}

One patient did not compete the study, therefore he was omitted along with his matched control child. Accordingly, 72 children in each group were studied. There is a statistically significant difference between both groups regarding mother and father education, age of fathers at conception (larger percentage of children with autism had highly educated mothers, more than half of healthy children had their parental age at conception $<30$ years).

There is non-significant difference between both groups regarding marital status of their parents, maternal age at conception, family income or blood consanguinity. Concerning family history of psychiatric disorders, one sixth of cases versus $2.8 \%$ of controls had positive family history $(\mathrm{p}<0.05)$ (Table 1). There was a statistically significant difference between 
case and control groups regarding history of induction of ovulation, hypertension during pregnancy, folic acid supplementation during $1^{\text {st }}$ trimester of pregnancy and use of anti D (all of thyem except for folic acid supplementation were significantly more prevalent among case group). However, there was a statistically non-significant difference between their antenatal history (Table 2).

Additionally, there was a statistically significant difference between cases and controls regarding postnatal hypoxia, and admission to NICU (all were similarly higher among case group). Interestingly, about one fifth within case group versus $5.56 \%$ of control group received artificial feeding $(\mathrm{p}<0.05)$ (Table 2).

There was a significant difference between the two groups in terms of reaction to others (Afraid, No wave bye bye and No recognition of mothers) along with delayed developmental milestones. All these reactions were deteriorated among case groups (Table 3). Eighteen patients (18.04\%) had mild degree of autism with CARS score of (21-27), $19.45 \%$ with moderate degree of autism (28-33), and $62.51 \%$ with severe autism (P34) (Figure 1). Out of ASD patients, $58.34 \%$ had mild to severe mental retardation (IQ $=20-70)$, $34.72 \%$ with below average mentality (IQ $=71-89)$, and $6.94 \%$ with normal mentality (IQ = 90-109). All children within control group had normal mentality (Figure 2).On doing logistic regression model for risk factors of ASD, age of father $(\mathrm{OR}=8.26)$,positive family historyof psychiatric diseases(OR=9.3), and postnatal hypoxia $(\mathrm{OR}=2.5)$ were significant risk factor. On the other hand, folic acid supplementation during 1sttrimester of pregnancy significantly protected from that $(\mathrm{OR}=0.21)$ (Table 4).

\section{Discussion:}

Mean age of the studied group was 6.8 years, and most children with ASD were males $(80.5 \%)$. The findings of the present study are in line with $\mathrm{CDC}^{(\mathbf{3})}$, which estimated that the ratio of female to male children with ASD is approximately one to five.

On the one hand, this study showed that fathers' old age (father $\geq 35$ years) during pregnancy was found in $36.1 \%$ of autistic children, but it was found in $13.9 \%$ of control group. Accordingly, there was a statistically significant difference between the two groups. On the other hand, the present study showed that high maternal age (mother $\geq 35$ years) during pregnancy was predicted in $5.56 \%$ of autistic children compared to $4.16 \%$ in the case of controls and this difference was statistically insignificant. This finding is in agreement with Yousef et al. ${ }^{(1)}$ who 
found that there was highly significant difference between case and control groups with regards to the age of father but nonsignificant difference in the case of mothers' age. Similarly, these results are in agreement with the study by Reichenberg et al. ${ }^{(15)}$ which demonstrated that there was an association between advancing paternal age and the risk of ASD. They concluded that males aged $\geq 35$ years old had higher risk of getting autistic children by 5.75 times, while advancing maternal age has no association with ASD.

These results are also in agreement with Kolevzon et al. ${ }^{(16)}$ who found that parenteral age is associated with an increased risk of ASD. But our results are in contrast with study by Marissa et al. ${ }^{(17)}$ who concluded that advanced maternal age, rather than paternal age, may pose greater risk for autism. A striking finding on ASD there is a risk for it to increase with the age of the parents, particularly the father, at the time of conception. ${ }^{(18)}$ In another study, relative risks of ASD were detected to be associated with advanced maternal and paternal age at 1.18 and 1.34, respectively ${ }^{(19)}$. Moreover, positive family history of psychiatric diseases is a significant risk factor for ASD. ${ }^{(20)}$

In terms of education, we found that $(58.33 \%)$ of fathers and $(59.72 \%)$ of mothers of autistic childern had university level of education; in comparison to (33.31\%), (16.6\%) for fathers and mothers of the control group respectively. This may be due to the educated parents had awareness and good observation for any signs or change of their children, and also highly educated parents busier than less educated parents, which may lead to increase susceptibility to autism. This conclusion comes in agreement with Elwardany et al. ${ }^{(21)}$

With regards tofamily income, $(20.8 \%)$ of cases compared with $(23.6 \%)$ of controls, had either enough or more net income, which is why there was no statistically significant differece in terms of income. Such findings were in contrast to Yousef et al. ${ }^{(11)}$ who reported that there was a significant difference between case and control groups.

The present study illustrated that (23.6\%) of parents had consanguinity degree. There was insignificant difference as regard this point in both case and control groups. On the one hand, this conclusion conforms to other studies that reported that consanguinity had no role in increasing autism predictability, such as the study conducted on an Iranian population. ${ }^{(22-23)}$ On the other hand, another Egyptian study showed that there was a correlation between consinguinity and autism. ${ }^{(24)}$ 
According to family history of psychiatric diseases; $(16.7 \%)$ of autistic children had family history of psychiatric diseases compared to $(2.8 \%)$ of control group, this difference was statistically significant. These results were in line with Sulvian and colleauges ${ }^{(20)}$ who found that the presence of any psychitaric disorders in first-degree relatives was a consistent and significant risk factor for ASD.

In terms of Antenatal factors; the present study found that autistic childern's mothers had induction of ovulation more than controls' mothers and the difference was statistically significant. This finding was consistent with a follow-up study in Denmark to assess the risk of ASD in children born after assisted conception ${ }^{(23)}$. However, this conclusion contraststo the results of Yousef and colleagues ${ }^{(11)}$ who found insignificant difference between case and control groups in terms of induction of ovulation. The difference may be due to different study populations and cultures.

The current study demonstrated that patients' mothers had gestational hypertension more than controls' mothers and the difference was statistically significant. In a former Egyptian study, it was reported that gestational hypertension was significantly higher in mothers of autistic children than in the control group. ${ }^{(25)}$ Our result, however disagree with another study where there was no significant difference between cases and control as regard hypertension during pregnancy. ${ }^{(23)}$

The present study showed that there were no statistically significance differences between case and control groups' mothers regarding bleeding during pregnancy and gestational diabetes and autism. But, Gardner et al. ${ }^{(18)}$ reported that there was an association between maternal bleeding during pregnancy and gestational diabetes and autism.

According to folic acid supplementation, $(79.17 \%)$ of cases' mothers compared with $(97.2 \%)$ of controls' mothers have received folic acid during 1sttrimester of pregnancy, which was statistically significant. This finding was in agreement with further study which denoted that folic acid intake was significantly associated with prevention of ASD. ${ }^{(27)}$

There was significant difference between cases' mothers and controls' mothers as regard Anti D intake, in agreement with ElBaz et al. (24) who found that there was significant different with regards to Anti D intake.

Regarding natal history, our study detected no significant difference between case and control groups in terms of labour, type of labour and birth weight, in harmony with 
findings of Yousef et al. ${ }^{(11)}$ Yet, such result disagreed with El-Baz et al., ${ }^{(24)}$ who found there was highly significant difference as regard method of delivery and birth weight increase incidence of autism among low birth weight .

As for postnatal hypoxia, $(20.83 \%)$ of cases versus $(4.16 \%)$ of controls were exposed to postnatal hypoxia, and the difference was statistically significant.

Therefore, regarding admission to Neonatal Intensive Care (NICU) $(22.22 \%)$ of cases versus $(4.2 \%)$ of controls, there was significant difference between them and it was detected that main cause of admission was hypoxia. This finding is consistent with other studies. $^{(24-26)}$

In terms of history of feeding, $(19.44 \%)$ of cases versus $(5.6 \%)$ of controls had artificial feeding, which was statistically significant. These results were in agreement with Schmidt et al. ${ }^{(27)}$ who detected that breast feeding protects todlers four times more from autism compared to artificial feeding as it provides essential fatty acids are necessary for the proper development of the brain and nervous system, are present in breast milk.

All studied developmental milestones were delayed in autistic children compared to control group's. In agreement with our findings, Visser and his colleagues ${ }^{(28)}$ demonestrate some of noted behaviours in autism which include: delayed speech and language skills, doesn't point orwave “'byebye" and delayed in acquiring motor activity, such asbicycle riding. They may be poorly coordinated or have an abnormal gait or posture, poor hand writing. Additionally, our results were in agreement with June and collagues ${ }^{(29)}$ who concluded that about $96 \%$ of autistic children had motor developmental delay. Qualitative impairment in social interaction and communication was also more commonly observed than restricted interests and activities.

Based on CARS Scores, $62.5 \%$ of our cases had severe degree of autism, in the same line with a previous stidy where $57 \%$ of cases had severe degree of autism, and $28 \%$ had moderate degree ${ }^{(24)}$. About $58 \%$ of studied ASD children had severe mental retardation this approximated to a previous Egyptian study ${ }^{(24)}$ where $55 \%$ of their patients with mild to severe mental retardation (IQ $=20-70)$. Folic acid supplementation during 1sttrimester of pregnancy $\quad(\mathrm{OR}=0.21,95 \% \quad \mathrm{CI}=0.06$, 0.71) was protective against ASD in the current study, while positivefamily history of psychiatric diseases $(\mathrm{OR}=9.3$, $95 \% \mathrm{CI}=1.71,35.98)$ and postnatal hypoxia $(\mathrm{OR}=2.5,95 \% \mathrm{CI}=1.22,18.83)$, were significant risk factors for ASD . 
These results agreed with that by Yousef et al. ${ }^{(11)}$, and also our results point that age of father> 35 was significant risk factor $(\mathrm{OR}=8.26,95 \% \quad \mathrm{CI}=1.9,19.93)$, in harmony with El-Baz et al. ${ }^{(24)}$ who found that age of father $>35$ is significant risk factor for ASD.

Conclusion: The most significant risk factors for early detection of autism are positive family history of psychiatric diseases, posnatal hypoxia, advanced paternal age and artificial feeding. Folic acid supplementation during $1^{\text {st }}$ trimester and befor conception is a protective from all neurodevelopemental disorders. These factors should be examined later on in the future studies that use large populationbasedbirth cohorts with precise assessments of exposures and potenial confounders.

The study had some limitation. It was applied in a single center. It is case control study with risk of recall bias. Also risk factors highlighted in this research reflected just associations. Actual role of each risk factor and time needed for it to produce ASD can not be determined. However; the study still had strength points as it included control group to weigh the studied risk factors and all children underwent psychiatric evaluation. This study can be a start for further prospective studies to understang magnitude and risk factors of such upsurging problem
Recommendations: Public awareness must be fostered about the risk factors and early signs of ASD as delayed speech and loss of eye to eye contact. Folic acid supplementation before coception and at the first trimester of pregnancy and/or eating a diet rich in folic acid (at least $600 \mathrm{mcg}$ per day) is mandatory for the prevention of ASD. All children should be screened with standardized developmental tools at specific intervals at the 9,18, 24 and 30 months for early detection of ASD. Prospective multicenter large scale studies should be done to verify these findings.

Funding: The research was funded by the authors.

Conflict of interest: The authors declared no conflict of interest.

Acknowledgment: Special thanks to all Psychiatry departement for their help and explantion tools which used in psychiatric evaluation and to all study participants.

\section{References:}

1. Branby G, Abbott A, Sykes N. Candidate-gene screening and association analysis at the autism - susceptibility Locus on chromosome 16p: evidence of association of GRIN2A and ABATAm. J Hum Genet2005;76:950-66.

2. Fombonne E. Is the prevalence of autism increasing? Journal of Autism and 
Developmental Disorders1996:, 26: 673676.

3. Centers for Disease Control and Prevention.Prevalence of autism spectrum disorder among children aged 8 Years, Autism and Developmental Disabilities Monitoring Network, 11 sites, United States, MMWR2014; 63 (No. SS 2):1-21.

4. Abdel Hameed MI.The Effectiveness of an Educational Training Program for Autistic Children's Mothers in the Development of Some of the Daily-Life Skills in their Children. Journal of American Science2015; 11 (2): 45-61.

5. Al-Ansari AM, Ahmed MM. Epidemiology of autistic disorder in Bahrain: prevalence and obstetric and familial characteristics. Mediterr Health J. 2013;19:769-774.

6. Eapen V, Mabrouk AA, Zoubeidi T et al. Prevalence of pervasive developmental disorders in preschool children in the UAE. J Trop Pediatr. 2007;53:202-205.

7. Al-Farsi YM, Al-Sharbati MM, Al-Farsi $\mathrm{OA}$ et al. Brief report: Prevalence of autistic spectrum disorders in the Sultanate of Oman. J Autism Dev Disord. 2011;41:821-825.

8. American Psychiatric Association. Diagnostic and statistical manual of mental disorders, 5th ed., Text Revision (DSM V), Washington, DC,2013.
9. Koea R, Kohnson JK, Koegel

RL.Behavioral assessment andcurriculum development. New York: Brunner/Mazel; 2-24. Disord2005; 16: 385-392.

10. Geschwind K.Association of fragile $X$ with autism. Am JPsychiatry2005 ;192:142-9.

11. Yousef SS, Amin GA, Abdel baky OM et al. Risk Factors of Autistic Spectrum Disorders (ASDs) among Egyptian children patients, The Egyptian Journal of Community Medicine 2017 ; 35 (2):7383.

12. Stanford-Binet International Scale. 4th ed., 2 years to adult, useful for handicapped children 1986.

13. Melika L. Stanford-Binet intelligence scale. 4th Arabic version. 2nd edition. Cairo: Victor Kiorlos Publication. 1998.

14. Schopler E, Reichler RJ, Renner BR: the childhood autism rating scale (CARS): for diagnostic screening and classification of autism. New York: Irvigton 1988.

15. Reichenberg A, Gross R, Weiser M.Advancing paternal age and autism. Arch Gen Psychiatry 2006 ; 63(9):10261032.

16. Kolevzon A, Gross R, Reichenberg A. Prenatal and perinatal riskfactors for autism: a review and integration of findings. ArchPediatr Adolesc Med.2007 ;161(4):326-33. 
17. Marissa DK, Christine F, Diana DB et al. Estimatedautism risk and older reproductive age. Am J Public Health2009:1673-1679.

18. Gardener H, Spiegelman D,Buka SL.Perinatal and Neonatal Risk Factors for Autism: A Comprehensive Metaanalysis. J. Pediatrics2011; 128(2):344355.

19. Croen LA, Daniel V,Najjar DV.Maternal and Paternal Age and Risk of Autism Spectrum Disorders. Arch Pediatr Adolesc Med.2007; 161(4):334340.

20. Sullivan PF, Magnusson C,Reichenberg A.Family History of Schizophrenia and Bipolar Disorder as Risk Factors for Autism.Arch Gen Psychiatry2012; 69(11):1099-1103.

21. Elwardany S, Ibrahim H, Askar G : Risk factors for Autistic Spectrum Disorders at Assiut City. Journal of Education and Practice 2013; 4 (28): 147 157.

22. Al-Salehi SM, Al-Hifthy EH, Ghaziuddin M: Autism in Saudi Arabia:Presentation, Clinical Correlates and Comorbidity, University of Michigan Medical Center, Journal of Transcultural Psychiatry2012; 49(5):110120.

23. Sasanfar R, Haddad SA , Tolouei A.Paternal age increases the risk for autism in an Iranian population sample. Molecular Autism2010; 1(1):1-10.

24. El-Baz F, Ismael NA, Nour ElDinSM. Risk factors for autism: An Egyptian study. The Egyptian Journal of MedicalHuman Genetics2011; 12: 31-38. 25. Hvidtjørn D, Grove J, Schendel D.Risk of autism spectrum disorders in children born after assisted conception: apopulation-based follow-up study. J Epidemiol Community Health 2011; 65: 497- 502.

26. Abd Elhameed MA, Abd Elbaky AO, Kamel EA. A Controlled Study of the Risk Factors and Clinical Picture of Children with Autism in an Egyptian Sample. The Egypt Journal of Neurology, Psychiatry and Neurosurgery2011; 48 (3): 271- 276.

27. Schmidt RJ, Tancredi DJ, Ozonoff S.Maternal periconceptional folic acid intake and risk of autism spectrum disorders and developmental delay in the CHARGE (CHildhood AutismRisks from Genetics and Environment) case-control study. Am J Clin Nutr.2012; 96(1): 80-89. 28. Visser JC, Rommelse N,Vink L.Narrowly Versus Broadly Defined Autism Spectrum Disorders: Differences in Preand Perinatal Risk Factors. Journal ofAutism and Developmental Disorders2013; 43(7): 1505-1516. 
29. Juneja M, Mukherjee SB, Sharma S. A

children with autism. Indian Pediatr descriptive hospital based study of 2005;42(5):453-8.

Table (1):Socio-demographic of the studied group

\begin{tabular}{|c|c|c|c|c|c|c|}
\hline \multicolumn{2}{|l|}{ Item } & \multicolumn{2}{|c|}{$\begin{array}{l}\text { Cases } \\
\mathrm{N}=72\end{array}$} & \multicolumn{2}{|c|}{$\begin{array}{c}\text { Control } \\
\mathrm{N}=72\end{array}$} & $P$ value \\
\hline \multirow[t]{4}{*}{ Marital status } & \multirow{2}{*}{ - $\quad$ Married } & $\mathrm{N}$ & $\%$ & $\mathrm{~N}$ & $\%$ & \multirow{4}{*}{0.94} \\
\hline & & 66 & 91.7 & 65 & 90.27 & \\
\hline & - $\quad$ Divorced & 4 & 5.6 & 5 & 6.93 & \\
\hline & - Widow & 2 & 2.7 & 2 & 2.8 & \\
\hline \multirow{6}{*}{$\begin{array}{l}\text { Education of } \\
\text { Mother }\end{array}$} & - Illiterate & 3 & 4.17 & 12 & 16.67 & \multirow[t]{6}{*}{$<0.001 *$} \\
\hline & - Read and write & 2 & 2.78 & 8 & 11.11 & \\
\hline & - $\quad$ Primary & 2 & 2.78 & 10 & 13.89 & \\
\hline & - Preparatory & 7 & 9.72 & 15 & 20.83 & \\
\hline & - Secondary & 15 & 20.83 & 15 & 20.83 & \\
\hline & - University & 43 & 59.72 & 12 & 16.67 & \\
\hline \multirow{5}{*}{$\begin{array}{l}\text { Age of mother at } \\
\text { conception of autistic } \\
\text { child in years }\end{array}$} & - $<20$ & 7 & 9.72 & 10 & 13.90 & \multirow[t]{5}{*}{0.95} \\
\hline & - $20-$ & 25 & 34.72 & 25 & 34.72 & \\
\hline & - 25- & 28 & 38.88 & 26 & 36.11 & \\
\hline & - $30-$ & 8 & 11.11 & 8 & 11.11 & \\
\hline & - $35-$ & 4 & 5.56 & 3 & 4.16 & \\
\hline \multirow[t]{6}{*}{ Education of Father } & - Illiterate & 5 & 6.94 & 12 & 16.66 & \multirow[t]{6}{*}{$0.003 *$} \\
\hline & - Read and write & 3 & 4.17 & 2 & 2.76 & \\
\hline & - $\quad$ Primary & 4 & 5.56 & 2 & 2.76 & \\
\hline & - Preparatory & 8 & 11.11 & 6 & 8.30 & \\
\hline & - Secondary & 10 & 13.89 & 26 & 36.11 & \\
\hline & - University & 42 & 58.33 & 24 & 33.31 & \\
\hline \multirow{3}{*}{$\begin{array}{l}\text { Age of father at } \\
\text { conception of autistic } \\
\text { child in Years }\end{array}$} & - $<30$ & 21 & 29.17 & 37 & 51.38 & \multirow[t]{3}{*}{$0.003^{*}$} \\
\hline & - $30-$ & 25 & 34.72 & 25 & 34.72 & \\
\hline & - $\quad \geq 35$ & 26 & 36.11 & 10 & 13.90 & \\
\hline \multirow{3}{*}{$\begin{array}{l}\text { Income/ month } \\
\text { (in Egyptian pounds) }\end{array}$} & - Not enough & 22 & 30.6 & 30 & 41.7 & \multirow[t]{3}{*}{0.22} \\
\hline & - Enough & 35 & 48.6 & 25 & 34.7 & \\
\hline & - $\quad$ Enough and more & 15 & 20.8 & 17 & 23.6 & \\
\hline \multirow[t]{2}{*}{ Consanguinity } & - No & 55 & 76.4 & 50 & 69.4 & \multirow[t]{2}{*}{0.34} \\
\hline & - Yes & 17 & 23.6 & 22 & 30.6 & \\
\hline \multirow{2}{*}{$\begin{array}{l}\text { Family history of } \\
\text { psychiatric diseases }\end{array}$} & - No & 60 & 83.3 & 70 & 97.2 & \multirow[t]{2}{*}{$0.004 *$} \\
\hline & - Yes & 12 & 16.7 & 2 & 2.8 & \\
\hline
\end{tabular}

* statistically significant 
Table (2):Comparison between cases and controls as regard Antenatal history of the mother

\begin{tabular}{|c|c|c|c|c|c|}
\hline \multirow{3}{*}{$\begin{array}{l}\text { Item } \\
\text { Antenatal history } \\
\text { - } \text { Induction of ovulation } \\
\text { - Bleeding } \\
\text { - Gestational diabetes } \\
\text { - Hypertension during pregnancy } \\
\text { - Preeclampsia } \\
\text { - } \text { Folic acid supplementation } \\
\text { - } \text { Use of Anti D }\end{array}$} & \multicolumn{2}{|c|}{$\begin{array}{l}\text { Cases } \\
\mathrm{N}=72\end{array}$} & \multicolumn{2}{|c|}{$\begin{array}{l}\text { Control } \\
\mathrm{N}=72\end{array}$} & \multirow{3}{*}{\begin{tabular}{|l|} 
P value \\
\\
$0.04 *$ \\
0.78 \\
1 \\
$0.01 *$ \\
0.14 \\
$<0.001 *$ \\
$<0.001^{*}$
\end{tabular}} \\
\hline & $\mathrm{N}$ & $\%$ & $\mathrm{~N}$ & $\%$ & \\
\hline & $\begin{array}{l}10 \\
8 \\
4 \\
15 \\
6 \\
57 \\
2\end{array}$ & $\begin{array}{l}13.8 \\
11.11 \\
5.56 \\
20.83 \\
8.33 \\
79.17 \\
2.78\end{array}$ & $\begin{array}{l}3 \\
7 \\
4 \\
5 \\
2 \\
70 \\
16\end{array}$ & $\begin{array}{l}4.17 \\
9.72 \\
5.56 \\
6.94 \\
2.78 \\
97.2 \\
22.22\end{array}$ & \\
\hline 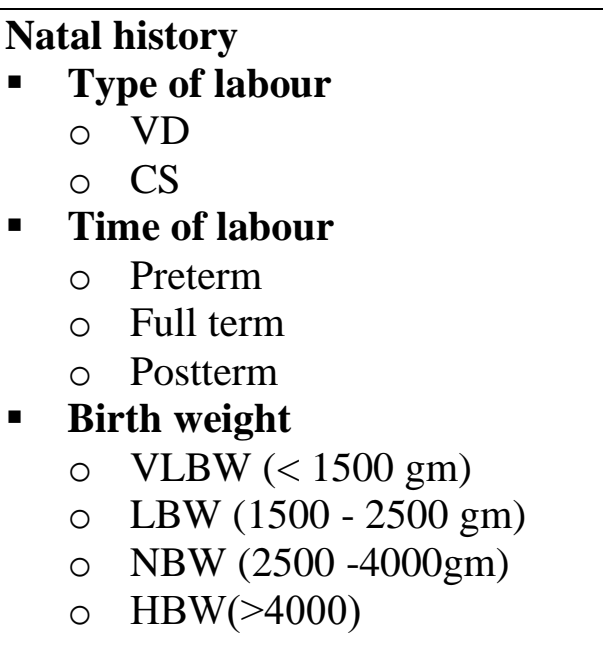 & $\begin{array}{l}34 \\
38 \\
5 \\
65 \\
2 \\
3 \\
11 \\
55 \\
3\end{array}$ & $\begin{array}{l}47.22 \\
52.78 \\
6.94 \\
90.28 \\
2.78 \\
\\
4.17 \\
15.28 \\
76.39 \\
4.16\end{array}$ & $\begin{array}{l}37 \\
35 \\
3 \\
67 \\
2 \\
2 \\
8 \\
60 \\
2\end{array}$ & $\begin{array}{l}51.38 \\
48.62 \\
4.17 \\
93.05 \\
2.78 \\
\\
2.78 \\
11.11 \\
83.33 \\
2.78\end{array}$ & \\
\hline 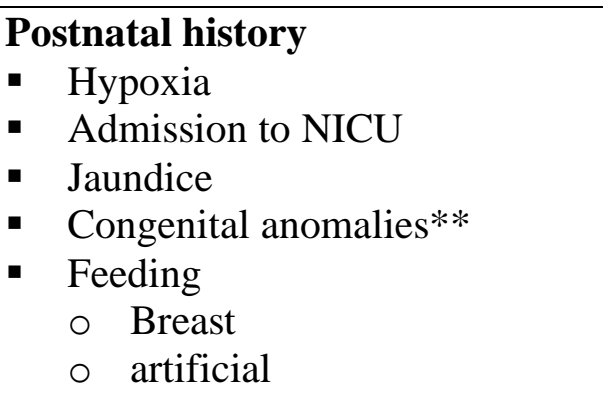 & $\begin{array}{l}15 \\
16 \\
28 \\
3 \\
\\
58 \\
14\end{array}$ & $\begin{array}{l}20.83 \\
22.22 \\
40.27 \\
4.16 \\
\\
80.56 \\
19.44\end{array}$ & $\begin{array}{l}3 \\
6 \\
33 \\
2 \\
\\
68 \\
4\end{array}$ & $\begin{array}{l}4.16 \\
8.33 \\
45.83 \\
2.78 \\
\\
94.44 \\
5.56\end{array}$ & $\begin{array}{l}0.002 * \\
0.02 * \\
0.39 \\
0.64 \\
0.01 *\end{array}$ \\
\hline
\end{tabular}

* Statistically significant

**Congenital anomalies are like polydactyl, hypospadias, anal anomalies and cardiac anomalies. 
Table (3): comparison between case and control as regarding developmental milestones

\begin{tabular}{|c|c|c|c|c|c|c|}
\hline \multicolumn{2}{|l|}{ Item } & \multicolumn{2}{|c|}{$\begin{array}{l}\text { Cases } \\
\mathrm{N}=72\end{array}$} & \multicolumn{2}{|c|}{$\begin{array}{l}\text { Control } \\
\mathrm{N}=72\end{array}$} & $P$ value \\
\hline \multirow{4}{*}{$\begin{array}{l}\text { Reaction to } \\
\text { others }\end{array}$} & \multirow[b]{2}{*}{ - Afraid } & $\mathbf{N}$ & $\%$ & $\mathbf{N}$ & $\%$ & \multirow[b]{2}{*}{$<0.001 *$} \\
\hline & & 30 & 41.67 & 9 & 12.5 & \\
\hline & - No wave bye bye & 43 & 59.72 & 2 & 2.78 & $<0.001$ \\
\hline & $\begin{array}{l}\text { - No recognition of } \\
\text { mothers }\end{array}$ & 36 & 50.0 & 0 & 0.0 & $<0.001$ \\
\hline \multirow{3}{*}{$\begin{array}{l}\text { Delayed } \\
\text { Developmental } \\
\text { milestones }\end{array}$} & - Delayed walking & 18 & 25.0 & 0 & 0.0 & $<0.001$ \\
\hline & - Delayed sitting & 11 & 15.28 & 0 & 0.0 & $<0.001$ \\
\hline & $\begin{array}{l}\text { - Delayed head } \\
\text { support }\end{array}$ & 10 & 13.89 & 0 & 0.0 & $<0.001$ \\
\hline \multirow[t]{3}{*}{ Hand writing } & - Rt & 67 & 93.0 & 65 & 90.28 & \multirow[t]{3}{*}{0.93} \\
\hline & - Lt & 4 & 5.5 & 6 & 8.33 & \\
\hline & - No writing & 1 & 1.5 & 1 & 1.39 & \\
\hline
\end{tabular}

*Statistically significant

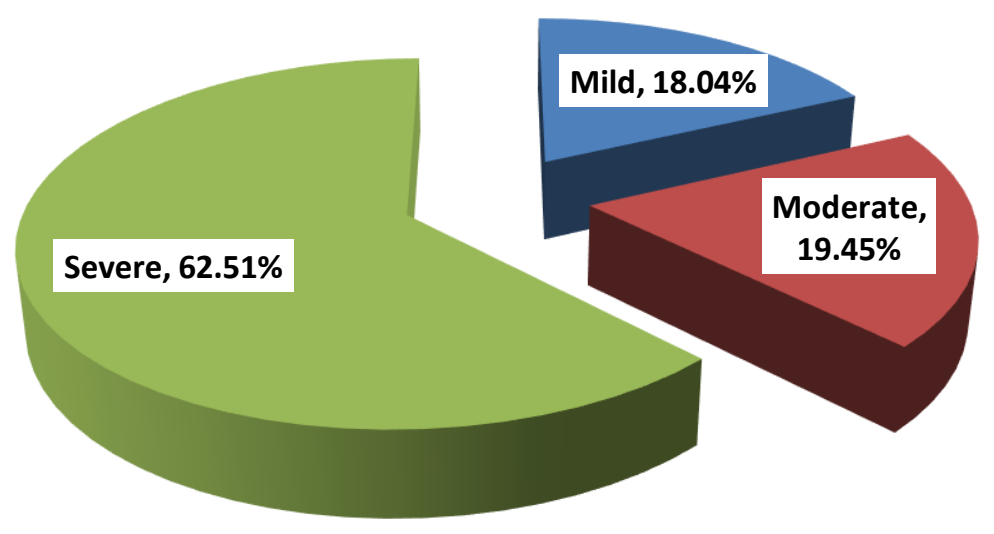

Figure (1): Distribution of the patients with ASD according to CARS score 


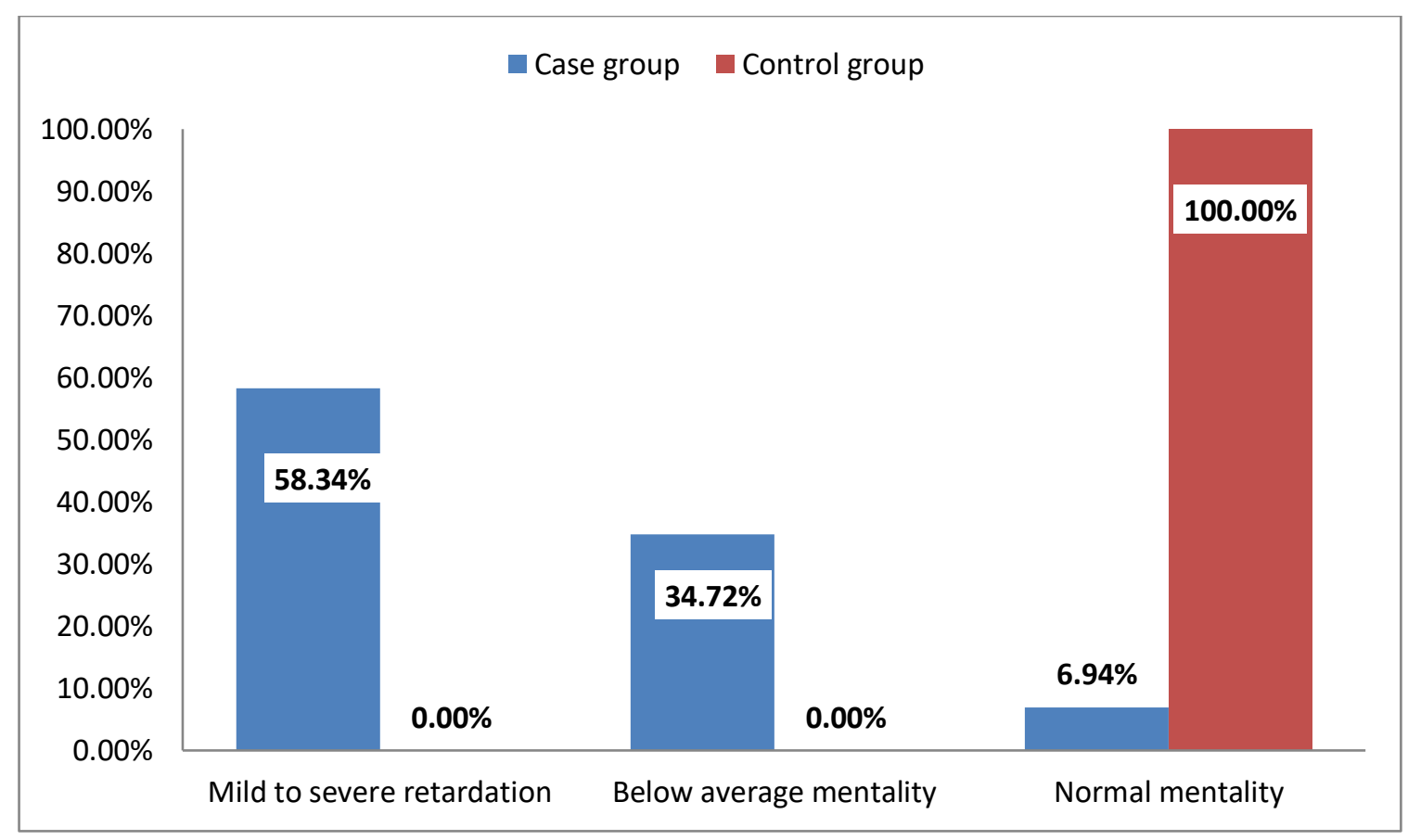

Figure (2) :Combined bar cahrt showing comparison between the studied groups regarding IQ test result

Table (4): Logistic Regression model for the Factors affecting ASD among studied group:

\begin{tabular}{|c|c|c|c|c|c|c|}
\hline \multirow[t]{2}{*}{ Item } & \multirow[t]{2}{*}{$\mathbf{B}$} & \multirow[t]{2}{*}{ S.E. } & \multirow[t]{2}{*}{ P value } & \multirow{2}{*}{$\begin{array}{l}\text { Odds } \\
\text { ratio }\end{array}$} & \multicolumn{2}{|c|}{ 95\% C.I. } \\
\hline & & & & & Lower & Upper \\
\hline - Age of father & 2.08 & 0.92 & $0.001 *$ & 8.26 & 1.9 & 19.93 \\
\hline $\begin{array}{ll}\text { - } & \text { Folic acid } \\
\text { during } \\
\text { - }\end{array}$ & -1.62 & 0.63 & $0.02 *$ & 0.21 & 0.06 & 0.71 \\
\hline $\begin{array}{l}\text { Postnatal } \\
\text { hypoxia }\end{array}$ & 1.55 & 0.72 & $0.03 *$ & 2.5 & 1.22 & 18.83 \\
\hline $\begin{array}{ll}\text { Positive family } \\
\text { history of } \\
\text { Psychiatric } \\
\text { disease }\end{array}$ & 2.01 & 0.81 & $0.001 *$ & 9.3 & 1.71 & 35.98 \\
\hline
\end{tabular}

*Statistically significant 


\section{الملخص العربي}

تقييم الجوانب الوبائية والسريرية والنفسية للأطفال المصابين بالتوحد بمركز الزقازيق الزيق

هناء ابو العز ايم نوفل ـأماني محمد عبداللهـ منى سامي حامد

الخلفيه العلميه: يعتبر التوحد اضطر ابًا نفسيًا شديدًا في مرحلة الطفولة يتسم بصعوبات شديدة في التو اصل اللفظي و غير اللفظي وتكوين علاقات مع أشخاص آخرين ، في تطوير اللغة ، و أنماط متكررة ومحدودة من السلوكيات

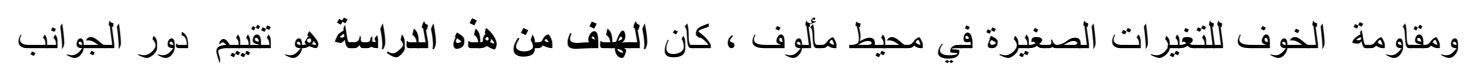

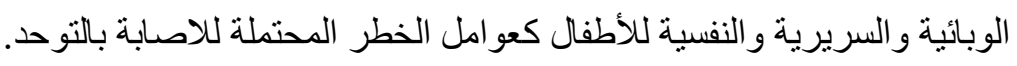
طرق البحث: الدراسة الحالية كانت دراسة الحالات والثوا هد. قمنا بدراسه 144 أمًا للأطفال لاستكمال استبيان حول عو امل الخطر المرتبطة بـالتوحد. تم دراسة اثثين وسبعين (72) حالة من الأطفال المصابين بالتوحد من قسم

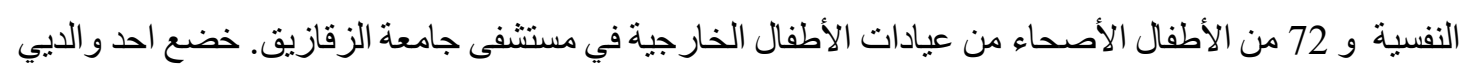
الاطفال لاستبيان لتوضيح عوامل الخطورة وخضع كل الاطفال لاختبار ستانفورد لتحديد العمر العقلي وكذلك الكي



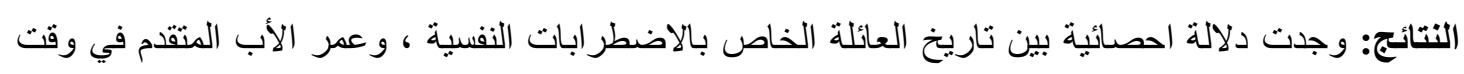

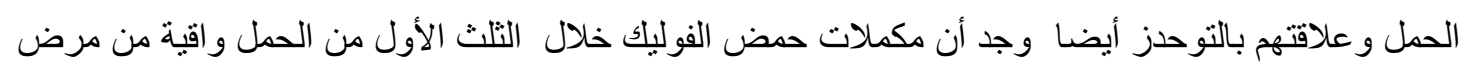

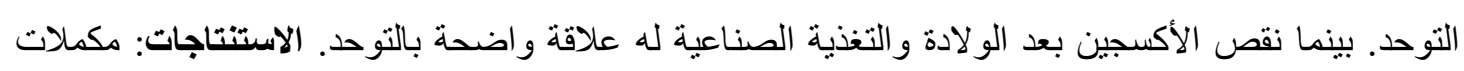



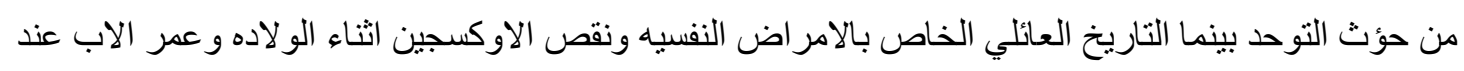
حدوث الحمل كانت هي عوامل الخطورة . 